\title{
A Study for the Restoration of Hong Dae-Yong Honsangui - Focusing on the structure and operating mechanism -
}

\author{
Yong Sam Lee ${ }^{1,2}$, Sang Hyuk Kim ${ }^{3 \dagger}$, Je Hoon Park ${ }^{1}$ \\ ${ }^{1}$ Department of Astronomy and Space Science, Chungbuk National University, Cheongju 361-763, Korea \\ ${ }^{2}$ Chungbuk National University Observatory, Cheongju 361-763, Korea \\ ${ }^{3}$ Korea Astronomy and Space Science Institute, Daejeon 305-348, Korea
}

\begin{abstract}
Honsangui (celestial globe) which is a water-hammering method astronomical clock is recorded in 「Juhaesuyong」 which is Volume VI of supplement from ${ }^{\circledR}$ Damheonseo』, written by Hong Dae-Yong (1731 1783). We made out the conceptual design of Hong Dae-Yong's Honsangui through the study on its structure and working mechanism. Honsangui consist of three rings and two layers, the structure of rings which correspond to outer layer is similar to his own Tongcheonui (armillary sphere) which is a kind of armillary sphere. Honsang sphere which correspond to inner layer depicts constellations and milky way and two beads hang on it as Sun and Moon respectively for realize the celestial motion. Tongcheonui is operated by the pendulum power but Honsangui is operated by water-hammering method mechanism. This Honsangui's working mechanism is the traditional way of Joseon and it was simplified the working mechanism of Shui yün $i$ hsiang t'ai which is a representative astronomical clock of China. This record of Honsangui is the only historical record about the water-hammering method working mechanism of Joseon Era and it provide the study of water-hammering method mechanism with a vital clue.
\end{abstract}

Keywords: Honsangui (celestial globe), Hong Dae-Yong, astronomical instrument, water-hammering method

\section{INTRODUCTION}

The various Korean cultural heritages in the area of astronomical science include the records of making a variety of clock instruments. The representative relics existing in our time are the water clock in Borugaknu (Borugaknu is the No. 229 National Treasure, newly made in 1536, but only the water clock part is remaining.), and the armillary sphere made by Song, I-Yeong (1619 1692) designated as No. 230 National Treasure (called as an alarm clock or an armillary clock). In addition to these, many clock instruments have been known only in the literature, among which representative ones are the water-hammering mothod Honui (armillary sphere) and Honsang (celestial globe) or Heumgyeonggakru (automatic water clock) made during the reign (1418 1450) of King Sejong, the armillary clock produced by Lee Min-Cheol (1631 1715) in the tenth year of Hyeonjong's reign (1650 1674), and Honsangui made by
Hong Dae-Yong (1731 1783) in the 18th century. All the clock instruments mentioned previously are mechanical clocks made in an elaborate and scientific manner in order to not only actuate the clock by the water-hammering mothod action mechanism using water as the driving force, but also simultaneously reproduce the armillary sphere or celestial globe, the appearace of the sky, as well as the rise and fall of the sun on the celestial body in real time. However, most of the clock instruments do not exist currently, and only the Borugaknu was reconstructed recently (reconstructed in 2007, National Palace Museum of Korea)

Hahn (2003) studied the Hong Dae-Yong Honsangui the book entitled, "The Astronomical Clock at Nongsugak." Hahn (2003) investigated the structure of Honsangui through a detailed analysis of the literatures about Honsangui found in the books <Nongsugak-uigiji (籠水閣儀器志)> and $<$ Geonjeondong-pildamsok (乾淨润筆談續) $>$ and also added detailed interpretation about the technical aspects (c) This is an open Access article distributed under the terms of the Creative Commons Attribution Non-Commercial License (http:// creativecommons.org/licenses/by-nc/3.0/) which premits unrestricted non-commercial use, distribution, and reproduction in any medium, provided the original work is properly cited.
Received Jul 17, 2013 Revised Aug 28, 2013 Accepted Aug 30, 2013 †Corresponding Author

E-mail: astro91@kasi.re.kr

Tel: +82-42-865-2046, Fax: +82-42-861-5610 
comparable to the celestial globes of China.

This study about the restoration of the Hong DaeYong Honsangui was conducted to understand the level of the science and technology at that time when it was produced and to provide important information needed for construction of the restored model.

\section{OUTWARD STRUCTURE AND WATER- HAMMERING SYSTEM OF HONSANGUI}

The record about Hong Dae-Yong Honsangui is found in 「Juhaesuyong (籌解需用) <Nongsugak-uigiji $>\lrcorner$ the Extra Collection Volume 6, and $\ulcorner$ Hangjeoncheokdok (杭傳尺 牘 $)<$ Geonjeongdong-pildamsok $>\lrcorner^{2}$ the Extra Collection Volume 3 of ${ }^{『}$ Damheonseo $\_$.

\subsection{Outward structure of Honsangui (渾象儀)}

The <Nongsugak-uigiji> contains the record about 3-Won (垣), five planets, 28-Su (宿), 360 constellations, and 11,520 celestial bodies (stars). The record is an explanation of the outline of the overall universe in addition to the explanation about the correlation between the universe and the human affairs. The record states that the positions of the celestial bodies and the angle of sun moving shold be measured after measuring the polar altitude (latitude), indicating that the calendar may be established and the accurate time may be known through these measurements.

Regarding the structure of Honsangui, the record descries that Honsangui has dual layers and has a structure similar to that of Tongcheonui (統天儀, armillry sphere). Honsangui is composed of an inner layer covering Honsanggu (Honsnag sphere) and an outer layer which is Honsanggu. The structural similarity may mean that the structure of Yukhapui (六合儀, armillary fixed outer component) corresponding to

${ }^{1\ulcorner J u h a e s u y o n g}$, the Extra Collection Vol. 6 of ${ }^{\circledR}$ Damheonseo ${ }_{\unlhd}$ : 22b: line 6 23a: line 10; 積氣胗廓 列曜森布 無情無朕 不可得以名狀也 乃若三垣五星 二十八宿 三百六十之官 萬有一千五百二十之數 參之人事 象以物形 割裂 牽合 以占样咱 吾不知其何說也 惟辰次分然後天可步也 䟭度明然後曆可治 也 昏中定然後時可協也 不有定界 測候何據 此列曜之所以不能無名而所由 來久矣 今立一儀 名日渾象 三環兩層 制同統天 糊紙正圓 剖而合之 全覆內 層 成一大球也 經緯分度 六等周羅 中外星官 燦然備載 銅絲縣珠 以象日月 銀河起沒 并合天象 轉而望之 若人之身昇九霄俯臨天體也. 赤道之南中南極 而設一環 亦爲三百五十九牙外設機輪 以水激之 機輪之制 設一木樻 高出 地平上安水孟 漏觜下垂 南北有柱 羊鑽圓敫 內藏一輪 廣寸徑尺 軸貫兩憿 北出櫃外 至于牙環 未施八牙 兩牙相受 四分輪周 繫以水喆 柄長數寸 四瑴 之輕重大小遠近低昂 務其均齊 兩壼之間 各設鐵尺 長出壷外 稍銳其端 可

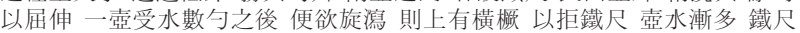

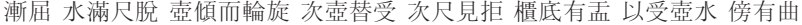
機 孟水逆行 上有小孟 以受機觜 如是累層 復注于樻上之孟一孟之水 互相 輸瀉 日添數勺任其周流袖手傍觀 允是䥻中之一天也. Source: The National Library of Korea, Book Number 古3648-文93-31, published in 1939.

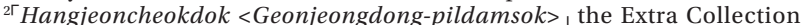
Volume 3 of 'Damheonseo „13b: line $12 \sim 14 \mathrm{a}$ : line 2; 別設一儀兩層 如原制糊 紙 虛中而正圓 中分之合于內儀之上而固其縫 成鷄卵之形 上圓周天星宿及 黃赤日月之道 其北極之環 自轉之法十字之機 皆同原儀 此制雖無日月之备 象而星宿度數 粲然可考 又原儀之所不及也. Source: The National Library of Korea, Book Number 古3648-文93-31, published in 1939. the outer layer is similar to that of Tongcheonui. Hence, there are three rings (Jaogyu, Jipyeonggyu, and Myoyugyu) on the outer layer, and Honsangu finished with sized paper forms the inner layer.

A modern celestial globe is convenient to seach and identify constellations by projecting the constellations in the night sky on the surface of the sphere. However, the structure of Joseon's Honsang enables to look at the inside from the outside of the sphere surface. Hong Dae-Yong stated about the constellations on the spheric surface of Honsangui, 'The sky is merged and rotated to view it(扞合天象 轉而望之). If a person's body stood on the nine celestial bodies, he would look down the celestial bodies(若人之身昇九霄俯臨天體 也).' This statement can be confirmed by the constelletions carved on the past celestial globes of China or Japan which are bilaterally symmetrical. The question is 'To view the stars carved on the sphere from the inside or from the outside?' It is understood that Honsang was an instrument in which the sphere was viewed from the outside of the sphere in order to observe and understand the universe.

\subsection{Water-hammering system}

The actuation of Honsangui is by the water-hammering method actuation of Giryun (機輪, mechanism wheel) at the outside. The Antarctic axis of Honsangui has 359-toothed gear which receives the driving force from the wheel apparatus to rotate Honsangu. The record of <Nongsugak-uigiji> about the water-hammering method actuation struction is as follows:

\section{$\ulcorner$ Juhaesuyong < Nongsugak-uigiji > the Extra Collection Volume 6 of ${ }^{『}$ Damheonseo}

A ring was installed at the south pole at the southern part of the equator, and the ring had 359-tooths. A mechanism wheel was established at the outside. The mechanism wheel of the waterhammering system was produced in the following method. A Mokgwe (木樻) is set up and its height is lower than the ground. A Suu (1) (水孟, Pasuho) containing water is put on the Mokgwe. Nuja (漏觜) is suspted below the Suu(1). A pillar is placed in the south-north direction, and a round holes are perforated through the pillar. A wheel is included in the pillar, and the width of the wheel is 1-Chon and the diameter is 1-Cheok. The axis penetrates both holes, protrudes from the Mokgwe to the north, reaches the tooths of the ring. 8-tooths at the tip support 2-teeths to divide the wheel circumference into four and to fasten the Suho (水壹). The length of the bag is several Chon. The lowering, heightening, and balanceing are controlled through the weight, size, and gap of the four Suhos. An Cheolcheok (鐵尺) between two Suhos is installed, and it is long enough to protrude the Suhos. The tip is a little sharp so that it may be bent or stretched. 
Table 1. Structural features of Honsangui (<Nongsugak-uigiji (籠水閣儀器志) $\rangle)$.

\begin{tabular}{|c|c|c|}
\hline Component parts & Structural features & Remarks \\
\hline $\begin{array}{l}\text { Jipyeonggyu } \\
\text { (地本規) }\end{array}$ & $\begin{array}{l}\text { - Labeled in Jipyeonggyu: } 24 \text {-direction, four seasons, long and short of Sun movement } \\
\text { - Fixed under the framework of the cross-shaped }\end{array}$ & \multirow{3}{*}{$\begin{array}{l}\text { Outer layer } \\
\text { (六合儀) }\end{array}$} \\
\hline $\begin{array}{l}\text { Jaogyu } \\
\text { (子午規) }\end{array}$ & $\begin{array}{l}\text { - Jaogyu erected north-south direction in Jipyeonggyu's vertically } \\
\text { - Polar axis: } 36 \text { degrees }\end{array}$ & \\
\hline $\begin{array}{l}\text { Myoyugyu } \\
\text { (卯西規) }\end{array}$ & $\begin{array}{l}\text { - Myougyu erected east-west (vernal equinox-autumnal equinox) direction in } \\
\text { Jipyeonggyu's vertically } \\
\text { - Or may be a description of the celestial equator }\end{array}$ & \\
\hline $\begin{array}{l}\text { Honsanggu } \\
\text { (渾象球) }\end{array}$ & $\begin{array}{l}\text { - Honsang sphere: Starched paper } \\
\text { - Latitude and longitude into six equal installments, around the constellation } \\
\text { - bead stringing copper-thread: Sun, Moom } \\
\text { Sun- Ilgyu (日規, Ecliptic), Moon-Wolgyu (月規, Moon's path) } \\
\text { - Honsang sphere's constellation: real constellation's symmetrical structure(left-right) } \\
\text { - Antarctic gear: 359-toothed wheel }\end{array}$ & Inner layer \\
\hline \multirow{4}{*}{$\begin{array}{l}\text { Water-hammering } \\
\text { system }\end{array}$} & 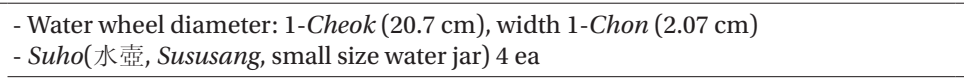 & Water wheel \\
\hline & $\begin{array}{l}\text { - Sue (1) (水孟, Pasuho, water supply jar) } \\
\text { - Nuja (漏觜, water supply valve) }\end{array}$ & Water clock \\
\hline & $\begin{array}{l}\text { - Cheolcheok (鐵尺, iron measure, delay appatus): between two Suhos } \\
\text { - Geolteok (threshold) }\end{array}$ & Escapement \\
\hline & $\begin{array}{l}\text { - Suu (2) (水㙉, Toesuho, waste water barket ) } \\
\text { - Gokgi (曲機, water pumping appratus) } \\
\text { - Gija (機觜, Gokgi's water supply valve) }\end{array}$ & $\begin{array}{c}\text { Toesuho } \\
\text { (退水铔) }\end{array}$ \\
\hline $\begin{array}{c}\text { Mokgwe } \\
\text { (木樻) }\end{array}$ & - Installed above the horizon: Suu(1) installed on Mokgwe (木樻; wooden crate) & \\
\hline
\end{tabular}

After a Suho receives water, it starts to pour the water out. A horizontal Geolteok (threshold) is installed over the Mokgwe, and its Cheolcheok is supported. As the amount of water contained in the bottle is increased gradually, the Cheolcheok is gradually bend. When the Suho is full of water, the Cheolcheok falls out and the Suho is inclined. Then, the wheel rotates, and the next Suho starts to receive water. The next Cheolcheok supports the Mokgwe. The Suu(2)(水㗐, Toesuho) at the bottom receives the water from the Suho, and the nearby Gokgi (曲機) turns the water in the $\operatorname{Suu}(2)$ in the reverse direction. A small Suu(1) in the back receives Gija (機觜, Gokgi's water supply valve). The structure consists of multiple layers, and water is supposed to be injected to the Suu(1) upon the Mokgwe. Water in one bowl moves from one bowl to another by being poured. Several cups of water is added each day to make the flow. In this way, the system reproduces 'a universe in bottles' without any intervention. ${ }^{3}$

A Suu(1) (水孟; Pasuho, water supply jar) supplying water is installed upon the Mokgwe (木櫃; wooden crate), the water is provided through a Nuja (漏觜; water supply valve) with a water wheel. The water wheel is installed as it is supported by a pillar. The water wheel is very small; the width is 1-Chon

${ }^{3}$ The translation of $\ulcorner$ Juhaesuyong $\lrcorner$ the Extra Collection Vol. 6 of ${ }^{『}$ Damheonseo was quoted from the material available at the website of Database of Korean Classics (http://db.itkc.or.kr).
( 寸, $2.07 \mathrm{~cm}$ ) and the diameter is 1-Cheok (尺, $20.7 \mathrm{~cm}$ ). Both axes of the wheel have eight toothed gears. Four Suhos (水跴; small size water jar) are installed to receive the water flowing through the Nuja. A sharp-end Cheolcheok (iron measure, delay appatus) is installed between two Suhos, and the material is flexible. The Cheolcheok is longer than the Suho. A horizontal Geolteok (threshold) on the Mokgwe is in contact with the Cheolcheok. As the amount of the water contained in the Suho is increased, the Cheolcheok is bent gradually. After a certain time, the Suho is inclided and the water wheel rotates. The water contained in the Suho is poured into the Suu(2) (水孟; Toesuho, waste water barket) below the water wheel. At that time, the Cheolcheok is supported by the Geolteok of the Mokgwe, and water is started to be contained in the next Suho. The water contained in the Suu(2) is pumped up to the Suu(1) on the Mokgwe by the Gokgi (曲機, water pumping apparatus). The water-hammering system of Hong Dae-Yong repeats these actions. Because both of the axes of the water wheel have 8-toothed gears, as the wheel rotates 45 times a day (32 minutes for one rotation), Honsanggu rotates once (one day) since it is interlocked with the 359-toothed gears at the southern part of Honsangui.

$<$ Geonjeongdong-pildamsok> also states that Honsanggu rotates around the polar axis, and indicates that the ecliptic, the equator, and the cross support were prepared according to the regulations, discussing the constellations on 


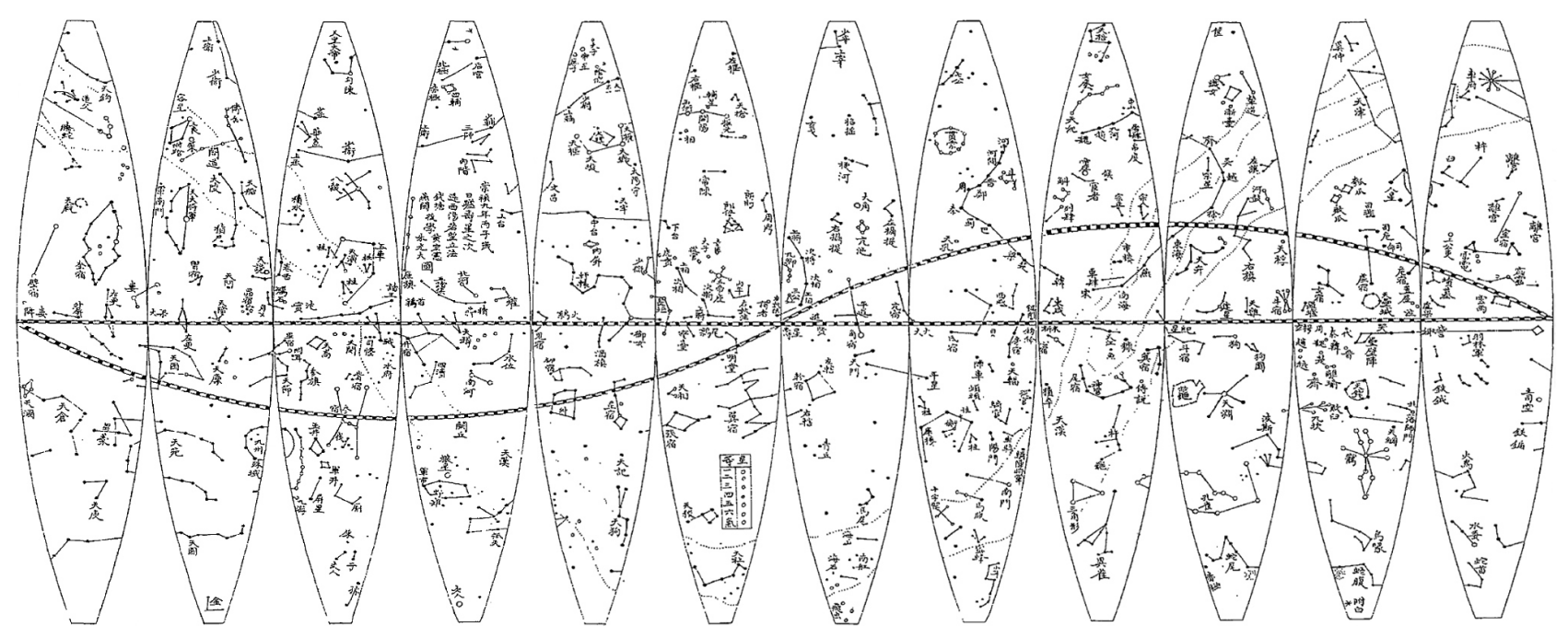

Fig. 1. Star chart of plane representation (『Sinbeopsanseo(新法算書)」).

Hongsanggu ${ }^{4}$ It is understood that Honsangui seemed to be installed at the center of a pond together with Tongcheonui and Hujong (候鍾, an alarm clock) to demonstrate the traditional Honui and Hongsang system.

On the basis of the record in <Nongsugak-uigiji $>$ presented above, the structural characteristics of Honsangui were identified as shown in Table 1. With respect to Ukhapui which was not directly mentioned in the dual layer structure of Honsangui, the structure of Tongcheonui was included in the description.

\section{CONCEPT DESIGN OF HONSANGUI}

Honsangui is divided into the Honsanggu part with which the constenllations in the sky are viewed, and the waterhammering system that actuates the Honsanggu part and generates driving force so that the Honsanggu part can be consistent with the revolution of the celestial bodies. Ham (2013) applied the original drawings of the constellations in the <Honcheonuiseol (渾天儀說) $>$ of ${ }^{『}$ Sinbeopsanseo (新 法算書) $\rrbracket^{5}$ to the recopnstruction of Honsang of late Joseon Dynasty. In ${ }^{\circledR}$ Sinbeopsanseo $o_{\Perp}$, the constellations are expressed by attaching a planar astronomical chart dvided into 12 pieces, each piece covering $30^{\circ}$, to Honsanggu (Fig. 1). It is assumed that Hong Dae-Yong Honsangui also expressed the stars on the sphere in the same manner.

Fig. 2 shows the driving force apparatus model of Hong

${ }^{4}<$ Geonjeondong-pildamsok $>$ contains the statement, "There is no true image of the sun and the moon." In contrast, <Nongsugak-uigiji> mentions the existence of the sun and the moon.

${ }^{5}{ }^{『}$ Sinbeopsanseo』Srouce: Munyeongaksagojeonseo (文淵閣四庫全書), Vol. 788: pp.306-308.

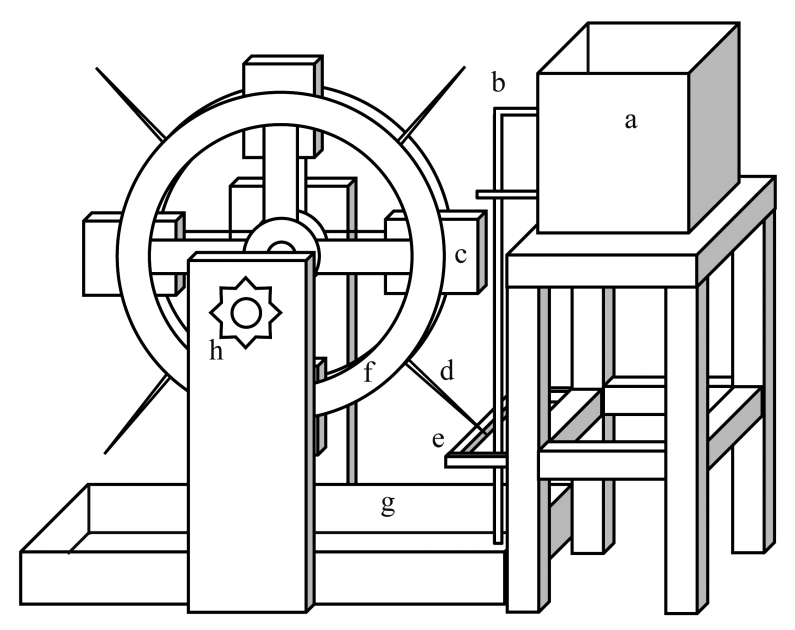

Fig. 2. Power model of Honsangui. a. Suu(1)(Pasuho, 播水壹), b. overflow, c Suho (水营), d. Cheolcheok (鐵尺), e. Geolteok, f. water wheel, g. Suu(2)(Toesuho, 退水营), h. mechanism wheel tooth (機輪牙)

Dae-Yong Honsangui. The water-hammering system that transmits driving force to Honsangui described in $<$ Nongsugak-uigiji> is composed of a water wheel, a water clock, an escapement, and a Toesuho (waste water barket). The size of the Suho suspending from the water wheel might have been as small as a few Chon, considering that the diameter and the width of the water wheel was 1-Cheok and 1-Chon, respectively. ${ }^{6}$ In the study by Park (2011), an Cheolcheok was installed at the bottom of the Suho,

\footnotetext{
${ }^{6}$ The Suho bottle in this study had the inner volume of about $7.9 \mathrm{~cm} \times 1.2$ $\mathrm{cm} \times 6 \mathrm{~cm}(h)$, containing about $57 \mathrm{~cm}^{3}$ of water. Considering the size of the Suho, the water wheel might have been operated with a very small amount of water, and the Cheolcheok might have been very flexible.
} 


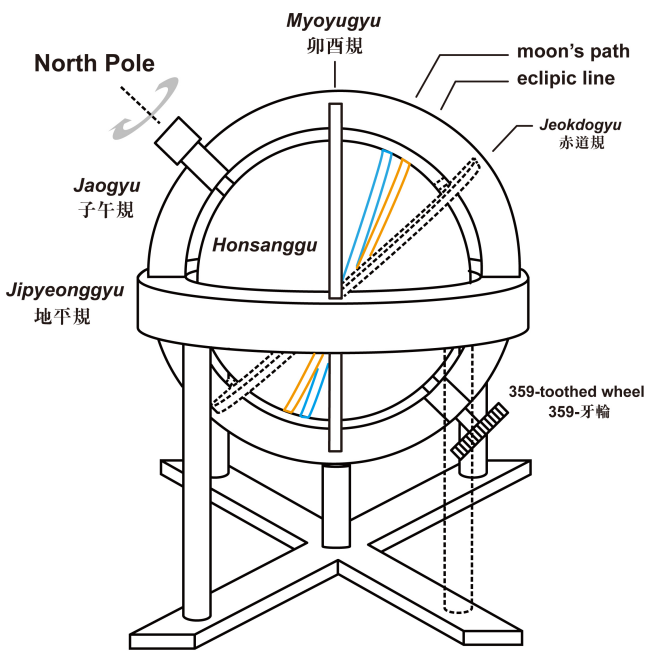

(a)
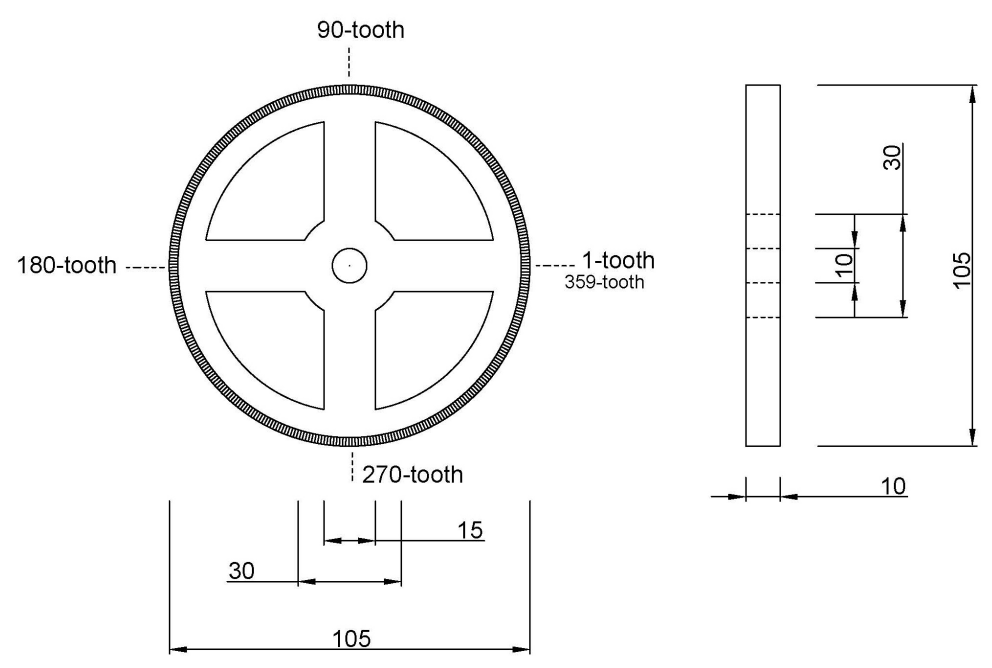

(b)

Fig. 3. Keys map (a) and 359-toothed wheel (b) of Honsangui.

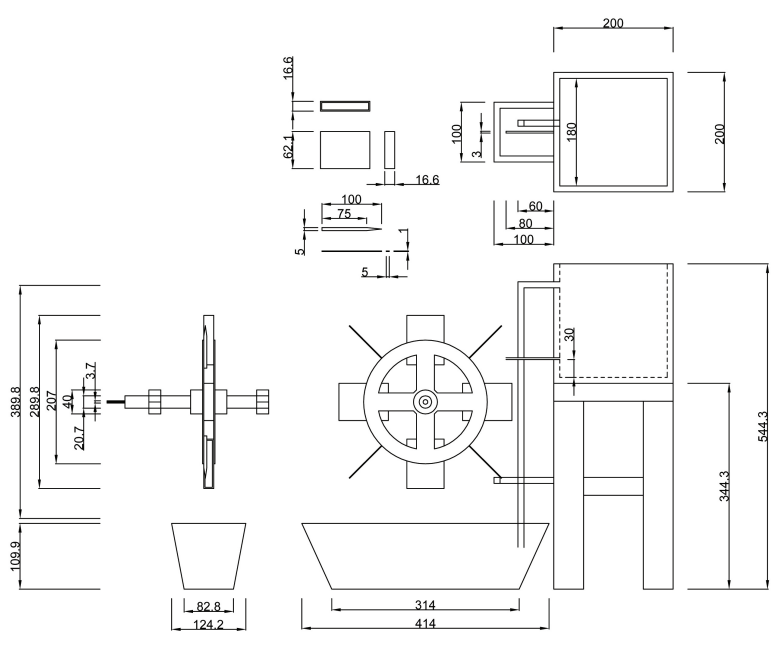

(a)
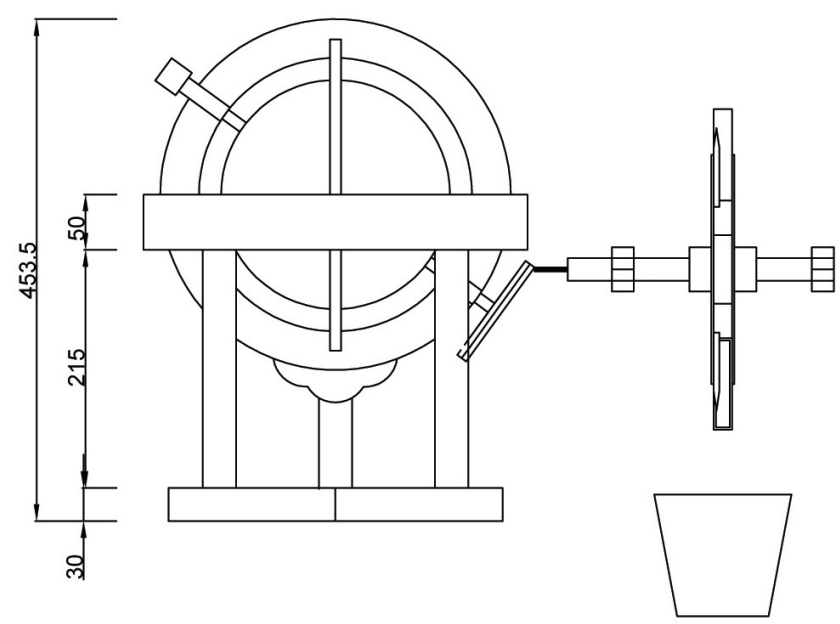

(b)

Fig. 4. Water-hammering system (a) and water power connection (b) of Honsangui.

referring to the actuating structure of the Cheonhyeong (天 衡, escapement) apparatus which is the excapement of Shui yün i hsiang t'ai (a representative astronomical clock of China). However, the literature indicates that the Cheolcheok is between two Suhos, and thus an improvement has to be made in this regard. By specifying the model studied by Park (2011), the conceptural drawing of Hong Dae-Yong Honsangui and the fundamental design plan of the waterhammering system were completed (Figs. 3 and 4).

Instead of Jeokdogyu (赤道規; equatorial ring) previously known to the conventional armillary sphere, Myoyugyu (卯西規) was introduced as Yukhapui of Hong Dae-Yong
Honsangui. Myoyugyu might have been mentioned as Myoyugyu because Jeokdogyu was assembled in the Myo (卯, east) direction and the $Y u$ (西, west) direction on the horizontal plane. Referring to the description about such Myoyugyu in the Western armillary sphere and the conceptual description about Myoyugyu in Chinese literature, Hahn (2003) asserted that Myoyugyu is different from the configuration of Yukhapui located at the outer layer of the conventional armillary sphere. Considering the statement in the literature, 'The top and the bottom of Myoyugyu are connected with the top and the bottom of $J a o g y u$ (萹卯西規 與子午規上下相結)' it seems appropriate 
to consider that Myoyugyu penetrates the zenith of Jaogyu.

In general, a water wheel accompanies a Pasuho of a water clock having the function of overflow in order to suppy a predetermined quantity of water. Shui yün i hsiang t'ai of 11th century and Borugaknu of 15th century had such a function. Kim et al. (2011) and Lee \& Kim (2012) presumed that the overflow method was also applied to Heumgyeonggaknu and the water-hammering type celestial globe. The generation and control of the driving force using the alarm clock Tongcheonui, which is another instrument in the Nongsugak, the personal observatory of Hong Dae-Yong, is by a weight and a foliot type escapement system. These correspond to the overflow and the Cheonhyeong apparatus (the system controlling the water wheel by measuring a predetermined quantity of water by measuring it with a balance). Thus, Hong Dae-yong might have realized the function of driving force control by water wheel and Suho by combining the overflow which supplies a predetermined quantity of water with the Cheolcheok (the apparatus having a sharp and flexible tip). Four Cheolcheoks were installed between a Suho and another. A Geolteok was installed under the Suho so that the Cheolcheok could be stopped.

The water contained in the Toesuho under the water wheel was re-supplied to the Pasuho upon the Mokgwe through Gokgi. Gokgi was not included in this conceptual design. $<$ Nongsugak-uigiji> does not provide a detailed description about the Gokgi, whether the water was automatically pumped up as being interlocked with the water wheel or the water was manual pumped up. Considering that the water-hammering system of Hong Dae-Yong is a small-scale experimental apparatus, contrary to the Shui yün $i$ hsiang $t^{\prime} a i$ of China or the water-hammering type armillary clock of Lee Min-Cheol, there is a bare possibility that Gokgi is an automated apparatus.

\section{CONCLUSIONS}

Honsangui is a water-hammering type celestial globe which Hong Dae-Yong installed at Nongsugak, his personal observatory. <Nongsugakuigiji> is the only literature explaining the water-hammering system of Joseon. Through the study on the structure and action mechanism of Hongsangui, we present following structural featurs.

First, Honsangui comprises the celestial globe where constellations were carved on the spheric surface and the water-hammering system that actuate the celestial globe. Second, Yukhapui in Honsangui is beyond the traditional form of Joseon, perhaps being affected by the Western armillary spheres. Third, the escapement of the water- hammering system was realized with a Pasuho having the apparatus for overflow and a Cheolcheok. Application of the Cheolcheok is beyond the traditional form of Joseon. Fourth a very small quantity of water should be supplied to the Suho installed at the water wheel, and the Cheolcheok should be highly flexible. Fifth, the Hong Dae-Yong water-hammering system was a small-scale experimental apparatus for private research.

Hong Dae-Yong's Nongsugak Honsangui succeeded the traditions of the astromonical clocks that had been operated from the early Joseon Dynasty, and was partially improved to have the unique ring structure and waterhammering system. Through the analysis of the records in $<$ Nongsugak-uigiji $>$ and < Geonjeondong-pildamsok $>$, we had a better understanding of the structur of the Hongsangui, and performed a basic conceptual design on the basis of the structure. An experimental analysis may be needed in the future study for the restoration of the Hong Dae-Yong's astronomical instruments. We hope that an improved restoration model of the celestial globes can be constructed through the experimental analysis.

\section{ACKNOWLEDGMENTS}

This work was supported by the research grant of the Chungbuk National University in 2011.

\section{REFERENCES}

Hahn YH, Astronomical Clocks of Nongsugak, Yeoksahakbo, 177, 1-32 (2003).

Ham SY, A study on the making Honsang, using the star catalogue of Nam Byeong-Gil's Seong Gyeong, MS Thesis, Chungbuk National University (2013).

Kim SH, Lee YS, Lee MS, A Study on the Operation Mechanism of Ongnu, the Astronomical Clock in Sejong Era, JASS, 28, 79-91 (2011). http://dx.doi. org/10.5140/JASS.2011.28.1.079

Lee YS, Kim SH, Structure and Conceptual Design of a Water-Hammering-Type Honsang for Restoration, JASS, 29, 221-232 (2012). http://dx.doi.org/10.5140/ JASS.2012.29.2.221

Park JH, A study on the flow control and escapement system of the water operated mechanical clock in Joseon Dynasty, Master Dissertation, Chungbuk National University (2011). 